\title{
ALUR PEMERIKSAAN SENGKETA TATA USAHA NEGARA MELALUI GUGATAN KE PENGADILAN TATA USAHA NEGARA
}

\author{
Syafri Ajis Murdanil \\ 191000360071 \\ UNIVERSITAS EKASAKTI
}

\section{A. PENDAHULUAN}

Indonesia adalah Negara Hukum, sebagaimana ditegaskan dalam ketentuan Pasal 1 ayat (3) Undang-Undang Dasar Negara Republik Indonesia Tahun 1945 (UUD 1945). Sebagai negara hukum Indonesia menganut konsepsi welfare state (negara kesejahteraan), sebagaimana diisyaratkan dalam alinea keempat Pembukaan UUD 1945, yang merupakan tujuan negara. Dalam konsepsi welfare state, pemerintah diberi wewenang yang luas untuk campur tangan (staatsbemoeienis) di segala lapangan kehidupan masyarakat dalam rangka menyelenggarakan kesejahteraan umum (bestuurszorg). Campur tangan tersebut tertuang dalam ketentuan perundangundangan, baik dalam bentuk undang-undang, maupun peraturan pelaksanaan lainnya yang dilaksanakan oleh administrasi negara, selaku alat perlengkapan negara yang menyelenggarakan tugas servis public.

Negara hukum pada dasarnya terutama bertujuan untuk memberikan perlindungan hukum bagi rakyat. Perlindungan hukum bagi rakyat terhadap tindakan pemerintahan dilandasi oleh dua prinsip; prinsip hak asasi manusia dan 
prinsip negara hukum. Dalam negara hukum, setiap penyelenggaraan urusan pemerintahan haruslah berdasarkan pada aturan hukum yang berlaku (wetmatigheid van bestuur). Sebagai konsekuensi dari negara hukum, wajib adanya jaminan bagi administrasi negara sebagai alat perlengkapan negara untuk dapat menjalankan pemerintahan dan warga negara memiliki hak dan kewajiban mendapat jaminan perlindungan. Oleh karena itu, kekuasaan pemerintah tidak dapat lepas dari perkembangan asas legalitas yang telah dimulai sejak konsep negara hukum klasik formele rechtstaat atau liberale rechtsstaat yaitu wetmatigheid van bestuur artinya pemerintahan menurut undang-undang. Setiap tindakan pemerintah harus berdasarkan kepada undang-undang.

Dalam melaksanakan fungsinya, aparat pemerintah mengadakan hubunganhubungan baik yang bersifat hubungan hukum maupun hubungan nyata dengan sesama aparat negara maupun dengan pihak perorangan baik yang berbentuk badan hukum maupun manusia pribadi (individu). Dalam menjalin hubungan hukum inilah terbentuk kegiatan-kegiatan atau aktivitas Pemerintah yang berunsurkan perbuatan-perbuatan aparat pemerintah. Dalam hukum administrasi yang penting adalah tindakan hukum, sebab suatu tindakan hukum akan menimbulkan akibat-akibat hukum tertentu bagi mereka yang terkena tindakan tersebut.

Menurut ketentuan Undang-undang No. 5 tahun 1986, tindakan hukum yang dilakukan oleh badan/pejabat tata usaha negara yang dituangkan dalam suatu 
keputusan (beschikking), harus merupakan tindakan hukum dalam lapangan hukum tata usaha negara (hukum publik).

Tindakan hukum yang dilakukan oleh badan/pejabat tata usaha negara yang dituangkan dalam suatu keputusan tata usaha negara (beschikking) dapat diuji keabsahannya melalui gugatan di Pengadilan Tata Usaha Negara (PTUN) apabila diduga bertentangan dengan peraturan perundang-undangan dan/atau bertentangan dengan asas-asas umum pemerintahan yang baik (AAUPB).

PTUN adalah salah satu pelaksana kekuasaan kehakiman bagi rakyat pencari keadilan terhadap sengketa tata usaha negara yang memiliki tugas dan wewenang untuk memeriksa, memutus dan menyelesaikan sengketa Tata Usaha Negara di tingkat pertama sebagaimana diamanatkan dalam Pasal 50 Undang-Undang No. 5 tahun 1986 tentang Peradilan Tata Usaha Negara.

Salah satu kewenangan PTUN yang paling penting selama proses pemeriksaan persidangan berlangsung adalah kewenangan untuk mengeluarkan suatu putusan (penetapan) sementara atau putusan sela atas keputusan pemerintah atau keputusan TUN yang sedang disengketakan. Begitu gugatan masuk dan didaftarkan di Kepaniteraan PTUN, pada saat itu juga PTUN dapat menghentikan keputusan pemerintah tersebut untuk tidak dilaksanakan, selama pemeriksaan proses perkara berlangsung. Putusan yang demikian disebut putusan penundaan, yang diatur di dalam Pasal 67 Undang-Undang No. 5 Tahun 1986. Pada asasnya suatu gugatan tidak menunda pelaksanaan keputusan TUN yang disengketakan (digugat). Asas tersebut bersumber pada asas bahwa setiap keputusan TUN harus 
dianggap sah menurut hukum (het vermoeden van rechtmatigheid $=$ praesumtio iustae causa). Karena keputusan itu dianggap demi kepastian hukum keputusan itu dapat dilaksanakan selama belum dibuktikan sebaliknya sampai ada pembatalan.

\section{B. PEMBAHASAN}

Sengketa Tata Usaha Negara adalah sengketa yang timbul dalam bidang tata usaha negara antara orang atau badan hukum perdata dengan badan atau pejabat tata usaha negara, baik di pusat maupun di daerah, sebagai akibat dikeluarkannya keputusan tata usaha negara, termasuk sengketa kepegawaian berdasarkan peraturan perundang-undangan yang berlaku.

Sengketa tata usaha negara ini diselesaikan di Pengadilan Tata Usaha Negara dengan mengajukan gugatan tertulis yang berisi tuntutan agar Keputusan Tata Usaha Negara yang disengketakan itu dinyatakan batal atau tidak sah, dengan atau tanpa Gugatan Melalui Pengadilan Tata Usaha Negara.

Pengadilan baru berwenang memeriksa, memutus dan menyelesaikan sengketa Tata Usaha Negara jika seluruh upaya administratif sudah digunakan. Apabila peraturan dasarnya hanya menentukan adanya upaya administratif berupa pengajuan surat keberatan, maka gugatan terhadap Keputusan Tata Usaha Negara yang bersangkutan diajukan kepada Pengadilan Tata Usaha Negara disertai tuntutan ganti rugi dan/atau direhabilitasi. 
Namun, jika peraturan dasarnya menentukan adanya upaya administatif berupa pengajuan surat keberatan dan/atau mewajibkan pengajuan surat banding administratif, maka gugatan terhadap Keputusan Tata Usaha Negara yang telah diputus dalam tingkat banding administratif diajukan langsung kepada Pengadilan Tinggi.

\section{Alur Pemeriksaan Gugatan Pada Pengadilan Tata Usaha Negara}

\section{Gugatan}

Gugatan adalah permohonan yang berisi tuntutan terhadap badan atau pejabat tata usaha negara dan diajukan ke pengadilan untuk mendapatkan putusan. Sehingga yang menjadi tergugat adalah badan atau pejabat tata usaha negara yang mengeluarkan keputusan berdasarkan wewenang yang ada padanya atau yang dilimpahkan kepadanya yang digugat oleh orang atau badan hukum perdata.

Sedangkan yang dimaksud dengan Keputusan Tata Usaha Negara, yang menjadi objek sengketa, adalah suatu penetapan tertulis yang dikeluarkan oleh badan atau pejabat tata usaha negara yang berisi tindakan hukum tata usaha negara yang berdasarkan peraturan perundang-undangan yang berlaku, yang bersifat konkret, individual, dan final, yang menimbulkan akibat hukum bagi seseorang atau badan hukum perdata. 
Yang tidak termasuk ke dalam kategori Keputusan Tata Usaha Negara dalam UU 5/1986 berserta perubahannya adalah:

a. Keputusan Tata Usaha Negara yang merupakan perbuatan hukum perdata;

b. Keputusan Tata Usaha Negara yang merupakan pengaturan yang bersifat umum;

c. Keputusan Tata Usaha Negara yang masih memerlukan persetujuan;

d. Keputusan Tata Usaha Negara yang dikeluarkan berdasarkan ketentuan Kitab Undang-Undang Hukum Pidana dan Kitab Undang-Undang Hukum Acara Pidana atau peraturan perundangundangan lain yang bersifat hukum pidana;

e. Keputusan Tata Usaha Negara yang dikeluarkan atas dasar hasil pemeriksaan badan peradilan berdasarkan ketentuan peraturan perundang-undangan yang berlaku;

f. Keputusan Tata Usaha Negara mengenai tata usaha Tentara Nasional Indonesia;

g. Keputusan Komisi Pemilihan Umum baik di pusat maupun di daerah mengenai hasil pemilihan umum.

Perlu diketahui bahwa gugatan dapat diajukan hanya dalam tenggang waktu 90 hari terhitung sejak saat diterimanya atau diumumkannya Keputusan Badan atau Pejabat Tata Usaha Negara. 


\section{Prosedur Dismissal}

Setelah diajukan gugatan, maka akan dilakukan pemeriksaan dismissal atau rapat permusyawaratan. Dalam rapat permusyawaratan ini, Ketua Pengadilan berwenang memutuskan dengan suatu penetapan yang dilengkapi dengan pertimbangan-pertimbangan bahwa gugatan yang diajukan itu dinyatakan tidak diterima atau tidak berdasar, dalam hal:

a. pokok gugatan tersebut nyata-nyata tidak termasuk dalam wewenang Pengadilan;

b. syarat-syarat gugatan tidak dipenuhi oleh penggugat sekalipun ia telah diberi tahu dan diperingatkan;

c. gugatan tersebut tidak didasarkan pada alasan-alasan yang layak;

d. apa yang dituntut dalam gugatan sebenarnya sudah terpenuhi oleh Keputusan Tata Usaha Negara yang digugat;

e. gugatan diajukan sebelum waktunya atau telah lewat waktunya.

Terhadap penetapan ini dapat diajukan Perlawanan kepada Pengadilan dalam tenggang waktu empat belas hari setelah diucapkan.Dalam hal perlawanan tersebut dibenarkan oleh Pengadilan, maka penetapan gugur demi hukum dan pokok gugatan akan diperiksa, diputus dan diselesaikan menurut acara 
biasa. Terhadap putusan mengenai perlawanan itu tidak dapat digunakan upaya hukum.

\section{Pemeriksaan Persiapan}

Sebelum pemeriksaan pokok sengketa dimulai, Hakim wajib mengadakan pemeriksaan persiapan untuk melengkapi gugatan yang kurang jelas. Dalam pemeriksaan persiapan Hakim:

a. wajib memberi nasihat kepada penggugat untuk memperbaiki gugatan dan melengkapinya dengan data yang diperlukan dalam jangka waktu tiga puluh hari;

b. dapat meminta penjelasan kepada Badan atau Pejabat Tata Usaha Negara yang bersangkutan.

Apabila dalam jangka waktu 30 hari penggugat belum menyempurnakan gugatan, maka Hakim menyatakan dengan putusan bahwa gugatan tidak dapat diterima._Terhadap putusan ini tidak dapat digunakan upaya hukum, tetapi dapat diajukan gugatan baru.

Setelah dilakukan pemeriksaan persiapan maka akan dilakukan pemeriksaan perkara untuk mendapatkan putusan. Terhadap putusan Pengadilan Tata Usaha Negara dapat dimintakan pemeriksaan banding oleh penggugat atau tergugat kepada Pengadilan Tinggi Tata Usaha Negara. Bahkan jika penggugat 
tidak juga puas dengan putusan tersebut, dapat dilakukan upaya hukum kasasi hingga upaya hukum luar biasa peninjauan kembali kepada Mahkamah Agung.

\section{PENUTUP}

Sengketa tata usaha Negara merupakan sengketa yang terjadi akibat adanya suatu Keputusan Tata Usaha Negara yang dikeluarkan oleh Badan atau Pejabat TUN yang dianggap merugikan Penggugat. Setelah melalui proses pengajuan gugatan dan pemeriksaan, maka proses yang paling penting dari seluruh rangkaian proses beracara di Peradilan Tata Usaha Negara tersebut adalah pelaksanaan putusan (eksekusi) terhadap putusan yang telah in kracht van gewijsde atau berkekuatan hukum tetap. Pelaksanaan putusan dalam Peradilan Tata Usaha Negara merupkan pelaksanaan dari apa yang telah diputus oleh hakim dalam proses pemeriksaan untuk mengembalikan hak-hak penggugat yang telah dilanggar oleh suatu Keputusan Tata Usaha Negara.

\section{DAFTAR PUSTAKA}

Darmini Roza dan Laurensius Arliman S Peran Pemerintah Daerah Di Dalam Melindungi Hak Anak Di Indonesia, Masalah-Masalah Hukum, Volume 47, Nomor 1, 2018.

Laurensius Arliman S, Komnas HAM dan Perlindungan Anak Pelaku Tindak Pidana, Deepublish, Yogyakarta, 2015.

Laurensius Arliman S, Penguatan Perlindungan Anak Dari Tindakan Human Trafficking Di Daerah Perbatasan Indonesia, Jurnal Selat, Volume 4, Nomor $1,2016$. 
Laurensius Arliman S, Problematika Dan Solusi Pemenuhan Perlindungan Hak Anak Sebagai Tersangka Tindak Pidana Di Satlantas Polresta Pariaman, Justicia Islamica, Volume 13, Nomor 2, 2016,

Laurensius Arliman S, Pelaksanaan Perlindungan Anak Yang Tereksploitasi Secara Ekonomi Oleh Pemerintah Kota Padang, Veritas et Justitia, Volume 2, Nomor 1, 2016.

Laurensius Arliman S, Kedudukan Ketetapan MPR Dalam Hierarki Peraturan Perundang-Undangan Di Indonesia, Lex Jurnalica, Volume 13, Nomor 3, 2016.

Laurensius Arliman S, Komnas Perempuan Sebagai State Auxialiary Bodies Dalam Penegakan Ham Perempuan Indonesia, Justicia Islamica, Volume 14, Nomor 2, 2017.

Laurensius Arliman S, Peranan Pers Untuk Mewujudkan Perlindungan Anak Berkelanjutan Di Indonesia, Jurnal Ilmu Hukum Tambun Bungai, Volume 2, Nomor 2, 2017.

Laurensius Arliman S, Mewujudkan Penegakan Hukum Yang Baik Untuk Mewujudkan Indonesia Sebagai Negara Hukum, Jurnal Hukum Doctrinal, Volume 2, Nomor 2, 2017.

Laurensius Arliman S, Participation Non-Governmental Organization In Protecting Child Rights In The Area Of Social Conflict, The 1st Ushuluddin and Islamic Thought International Conference (Usicon), Volume 1, 2017.

Laurensius Arliman S, Partisipasi Masyarakat Dalam Pembentukan PerundangUndangan Untuk Mewujudkan Negara Kesejahteraan Indonesia, Jurnal Politik Pemerintahan Dharma Praja, Volume 10, Nomor 1, 2017, https://doi.org/10.33701/jppdp.v10i1.379.

Laurensius Arliman S, Peran Komisi Perlindungan Anak Indonesia Untuk Mewujudkan Perlindungan Anak, Jurnal Respublica Volume 17, Nomor 2, 2018.

Laurensius Arliman S, Menjerat Pelaku Penyuruh Pengrusakan Barang Milik Orang Lain Dengan Mempertimbangkan Asas Fungsi Sosial, Jurnal Gagasan Hukum, Volume 1, Nomor 1, 2019. 
Laurensius Arliman S, Ilmu Perundang-Undangan Yang Baik Untuk Negara Indonesia, Deepublish, Yogyakarta, 2019.

Laurensius Arliman S, Isdal Veri, Gustiwarni, Elfitrayenti, Ade Sakurawati, Yasri, Pengaruh Karakteristik Individu, Perlindungan Hak Perempuan Terhadap Kualitas Pelayanan Komnas Perempuan Dengan Kompetensi Sumber Daya Manusia Sebagai Variabel Mediasi, Jurnal Menara Ekonomi: Penelitian dan Kajian Ilmiah Bidang Ekonomi, Volume 6, Nomor 2, 2020.

Laurensius Arliman S, Pendidikan Kewarganegaraan, Deepublish, Yogyakarta, 2020.

Laurensius Arliman S, Makna Keuangan Negara Dalam Pasal Pasal 23 E UndangUndang Dasar 1945, Jurnal Lex Librum, Volume 6, Nomor 2 Juni 2020, http://dx.doi.org/10.46839/11jih.v6i2.151.

Laurensius Arliman S, Kedudukan Lembaga Negara Independen Di Indonesia Untuk Mencapai Tujuan Negara Hukum, Kertha Semaya Journal Ilmu Hukum, Volume 8, Nomor 7, 2020.

Laurensius Arliman S, Pelaksanaan Assesment Oleh Polres Kepulauan Mentawai Sebagai Bentuk Pelaksanaan Rehabilitasi Bagi Pecandu Dan Korban Penyalahgunaan Narkotika, Jurnal Muhakkamah, Volume 5, Nomor 1, 2020.

Laurensius Arliman S, Aswandi Aswandi, Firgi Nurdiansyah, Laxmy Defilah, Nova Sari Yudistia, Ni Putu Eka, Viona Putri, Zakia Zakia, Ernita Arief, Prinsip, Mekanisme Dan Bentuk Pelayanan Informasi Kepada Publik Oleh Direktorat Jenderal Pajak, Volume 17, No Nomor, 2020.

Larensius Arliman S, Koordinasi PT. Pegadaian (Persero) Dengan Direktorat Reserse Narkoba Polda Sumbar Dalam Penimbangan Barang Bukti Penyalahgunaan Narkotika, UIR Law Review, Volume 4, Nomor 2, 2020, https://doi.org/10.25299/uirlrev.2020.vol4(1).3779.

Laurensius Arliman S, Tantangan Pendidikan Kewarganegaraan Pada Revolusi 4.0, Ensiklopedia Sosial Review, Volume 2, Nomor 3, 2020.

Muhammad Afif dan Laurensius Arliman S, Protection Of Children's Rights Of The Islamic And Constitutional Law Perspective Of The Republic Of Indonesia, Proceeding: Internasional Conference On Humanity, Law And Sharia (Ichlash), Volume 1, Nomor 2, 2020. 
Otong Rosadi danLaurensius Arliman S, Urgensi Pengaturan Badan Pembinaan Idelogi Pancasila Berdasarkan Undang-Undang Sebagai State Auxiliary Bodies yang Merawat Pancasila dalam Perspektif Hak Asasi Manusia, Prosiding Konferensi Nasional Hak Asasi Manusia, Kebudayaan dan Tujuan Pembangunan Berkelanjutan Indonesia pada Masa Pandemi Covid19: Tantangan untuk Keilmuan Hukum dan Sosial Volume 1, Universitas Pancasila, Jakarta, 2020. 